\title{
Effect of different dietary fats on the content of fatty acids in the the blood serum and in the longissimus dorsi muscle of rats
}

\author{
Ewa Sawosz', Jadwiga Chachułowa ${ }^{1}$, R. Lechowski ${ }^{2}$, \\ Sz. Fiedorowicz' ${ }^{1}$ and Iwona Kosieradzka ${ }^{1}$ \\ 'Department of Animal Nutrition and Feed Management, \\ Agricultural University \\ Rakowiecka 26/30, 02-528 Warszawa, Poland \\ 'Department and Clinic of Internal Medicine, Agricultural University \\ Grochowska 272, 03-849 Warszawa, Poland
}

(Received 17 April 1998; accepted 19 November 1998)

\section{ABSTRACT}

Fourty eight rats divided into 6 groups were fed semi-purified mixtures with different kind of fats $(6 \%)$; C - control group, $\mathrm{T}$ - tallow, $\mathrm{L}$ - lard, $\mathrm{RO}$ - rape seed oil, $\mathrm{LO}$ - linseed oil, FO - fish oil.The percentage content of fatty acids in the serum and in the longissimus dorsi muscle (l.d.m.) of rats was measured.

The dietary fat did not influence the percentage content of saturated fatty acids (SFA) in the rat's serum. Increasing the percentage content of polyunsaturated fatty acids (PUFA) in serum and muscle at the expense of monounsaturated fatty acids (MUFA) was observed in rats receiving linseed oil. Feeding linseed oil and fish oil increased the content of PUFA with serum, in the l.d.m. of rats a negative correlation between PUFA ${ }_{n-3}$ and ${ }_{n-6}$ was not found.

KEY WORDS: fatty acids, fats, linseed oil, fish oil, serum, longissimus dorsi muscle, rats

\section{INTRODUCTION}

Polyunsaturated fatty acids (PUFA), especially the n-3 series, belong to one of the most deficient compounds of human and animal diet (Keys et al., 1986; Dolecek et al., 1992). Recent studies have demonstrated that increased intake of PUFA leads to an increased incorporation of these fatty acids into the plasma lipids and tissues (Broughton et al., 1991; Vidgren et al., 1997). Dietary fats, however, are not only the source of beneficial fatty acids, but also the source of undesirable 
saturated fatty acids (Mattson and Grundy, 1985). The accumulation of optimal fatty acids mainly depends on the dietary intake of these acids and the synthesis of endogenous fatty acids, as well as the relationships between incorporating particular groups or series of fatty acids into particular tissues. Thus, quality and quantity, as well as the combination of supplemented fatty acids seem to be important. The present study was carried out on rats to examine the effects of diets containing different fats on the serum and the longissimus dorsi muscle groups and series of fatty acids.

\section{MATERIAL AND METHODS}

\section{Animals}

Fourty eight male rats Wistar were divided into 6 groups of 8 . The average body weight of rats was $87 \mathrm{~g}(82-95.5 \mathrm{~g})$ at the beginning and $178 \mathrm{~g}(166.4-215.5 \mathrm{~g})$ at the end of the experiment. Rats were kept in individual standard cages for 36 days. For blood collection rats were anaesthetized using ketamine at a dose of $50 \mathrm{mg} / \mathrm{kg}$ body weight intramuscularly after $12 \mathrm{~h}$ fasting. After opening the abdominal cavity the blood was collected from vena cava abdominalis and serum prepared by centrifugation at $1000 \mathrm{xg}$. Rats were euthanasized by an overdose of ketamine and samples of longissimus dorsi musculus (1.d.m.) were taken for analysis.

\section{Feeding}

Rats received semi-purified mixtures, balanced according to the NRC (1978); the chemical composition of the mixtures is shown in Table 1. The diet consisted of (in \%): casein, 17; sucrose, 10; wheat starch, $57.86(62.86$, in the control group C); cellulose, 4; DL - methionine, 0.14; vitamins, 2; minerals, 3 supplemented with $6 \%$ tallow, group $\mathrm{T}$; lard, group L; rape seed oil, group $\mathrm{RO}$; linseed oil, group LO; fish oil, group FO, supplemented with vitamin and mineral mixtures. The vitamin mixture contained ( $\mathrm{mg}$ in $\mathrm{kg}$ ): vit.A, 20000 i.u.; vit. $\mathrm{D}_{3}, 2000$ i.u.; vit.E, 100 i.u.; vit. K, 5; choline, 200; p-amino benzoesic acid, 100; inositol, 100; niacin, 40 ; riboflavin, 8 ; thiamine, 5 ; pyridoxine, 5 ; folic acid, 2 ; biotin, 0.4 ; cyanocobalamine, 0.03; the mineral mixtures contained ( $\mathrm{g}$ in $\mathrm{kg}$ ): $\mathrm{CaHPO}_{4}, 735.0 ; \mathrm{K}, \mathrm{HPO}_{4}$, $81.0 ; \mathrm{K}_{2} \mathrm{SO}_{4}, 68 ; \mathrm{NaCl}, 30.6 ; \mathrm{CaCO}_{3}, 21.0 ; \mathrm{Na}_{2} \mathrm{HPO}_{4}, 21.4 ; \mathrm{MgO}, 25.0$; ferric citrate, 5.58; $\mathrm{ZnCO}_{3}, 30.81 ; \mathrm{MnCO}_{3}, 4.21 ; \mathrm{CuCO}_{3}, 0.23 ; \mathrm{KJ}, 0.01 ;$ citric acid, 7.06.

The percentage content of fatty acids in diets is shown in Table 2 . The diet for the control group was supplemented with $1 \%$ of soyabean oil to prevent deficiency of essential fatty acids in rats. 
TABLE 1

Chemical composition of diets, $\%$

\begin{tabular}{lrrrrrr}
\hline & \multicolumn{7}{c}{ Groups } \\
\cline { 2 - 7 } Items & control & tallow & lard & rape seed oil & linseed oil & fish oil \\
\hline Dry matter & 86.71 & 87.24 & 87.70 & 86.30 & 87.02 & 87.51 \\
Crude protein & 15.49 & 15.20 & 15.45 & 15.56 & 15.51 & 15.33 \\
Ether extract & 1.05 & 5.55 & 5.76 & 5.71 & 5.90 & 6.00 \\
Crude fibre & 2.75 & 3.02 & 2.4 & 2.79 & 3.12 & 2.69 \\
N-free extractives & 64.38 & 60.88 & 61.1 & 60.02 & 59.75 & 60.75 \\
Ash & 3.04 & 2.59 & 2.99 & 2.22 & 2.74 & 2.74 \\
\hline
\end{tabular}

TABLE 2

Content of fatty acids in fat of diet, $\%$

\begin{tabular}{|c|c|c|c|c|c|c|}
\hline \multirow[b]{2}{*}{ Fatty acid } & \multicolumn{6}{|c|}{ Groups } \\
\hline & $\begin{array}{c}\text { soyabean } \\
\text { oil (control) }\end{array}$ & tallow & lard & $\begin{array}{c}\text { rape } \\
\text { seed oil }\end{array}$ & linseed oil & fish oil \\
\hline $14: 0$ & 1.2 & 3.3 & 1.4 & 0.1 & 0.1 & 5.3 \\
\hline $15: 0$ & & 0.7 & 0.1 & & & 0.5 \\
\hline $16: 0$ & 11.8 & 28.1 & 23.7 & 5.0 & 5.6 & 14.2 \\
\hline $16: 1_{n-7}$ & 0.1 & 3.7 & 2.9 & 0.3 & 0.1 & 6.9 \\
\hline $17: 0$ & & 1.5 & 0.4 & & & \\
\hline $17: 1_{n-8}$ & & 0.4 & 0.4 & & & \\
\hline $18: 0$ & 4.2 & 27.4 & 12.4 & 1.7 & 5.9 & 3.3 \\
\hline $18: 1_{n-7}$ & 0.6 & 1.2 & 3.2 & 3.4 & 0.6 & 3.8 \\
\hline $18: 1_{n-9}$ & 22.8 & 29.9 & 44.6 & 53.3 & 22.0 & 23.2 \\
\hline $18: 2_{n-6}$ & 52.6 & 1.9 & 7.5 & 21.4 & 16.4 & 7.2 \\
\hline $18: 3_{n-3}$ & 6.6 & 0.5 & 0.7 & 9.4 & 48.8 & 3.3 \\
\hline $18: 3_{n-6}$ & & & & & & 0.2 \\
\hline $20: 0$ & & 0.4 & 0.2 & 0.6 & 0.2 & 0.3 \\
\hline $20: 1_{n-9}$ & 0.1 & & 1.2 & 2.1 & 0.2 & 1.5 \\
\hline $20: 2_{n-6}$ & & & 0.4 & 0.1 & & 0.2 \\
\hline $20: 4_{n-6}$ & & & 0.2 & & & \\
\hline $20: 5_{n-3}$ & & & & 0.3 & & 14.2 \\
\hline $22: 0$ & & & & & & 1.0 \\
\hline $22: 1_{n-9}$ & & & & 2.0 & & 0.8 \\
\hline $22: 5_{n-3}$ & & & s0.1 & & & 2.4 \\
\hline $22: 6_{n-3}$ & & & 0.1 & & & 9.5 \\
\hline $24: 0$ & & & & 0.1 & 0.1 & 0.1 \\
\hline $24: 1_{n-9}$ & & & & 0.2 & & 1.6 \\
\hline
\end{tabular}




\section{Analytical methods}

Fatty acids: a sample ( $1 \mathrm{~g})$ of tissue from longissimus dorsi was extracted with methanol and chloroform (2:1) according to Folsh et al. (1957). Methyl esters were prepared by estrification with $12-\%$ boron-trifluoride and extraction with iso-octane. The methyl esters were analysed in a HP 5890 gas chromatograph (SGE Inc.Austin), using a BPX $70-50 \mathrm{~m} \times 0.22 \mathrm{~mm} \times 0.25 \mathrm{~mm}$ column with FID detector, injection temperatures of $220^{\circ} \mathrm{C}$, column programmable temperature $\left(140-212^{\circ} \mathrm{C}\right)$. Helium was applied to determine fatty acids. Individual fatty acid peaks were identified in comparison with known reference esters.

Fatty acids were divided into groups: SFA $=14: 0+15: 0+16: 0+17: 0+18: 0+$ $20: 0+22: 0+24: 0 ;$ MUFA $=16: 1_{n-7}+17: 1_{n-8}+18: 1_{n-7}+18: 1_{n-9}+20: 1_{n-9}+22: 1_{n-9}+$ 24:1 $1_{n-9} ;$ PUFA $=$ PUFA $_{n-6}+$ PUFA $_{n-3}$ and series: MUFA $_{n-9}=18: 1_{n-9}+20: 1_{n-9}+22: 1_{n-9}+$ $24: 1_{n-9} ;$ PUFA $_{n-6}=18: 2_{n-6}+18: 3_{n-6}+20: 2_{n-6}+20: 4_{n-6}+22: 4_{n-6} ;$ PUFA $_{n-3}=18: 3_{n-3}+$ $20: 5_{n-3}+22: 5_{n-3}+22: 6_{n-3}$.

Dry matter, crude protein ( $\mathrm{N} \times 6.25)$, ether extract and crude fibre of the diets were determined as described by AOAC (1990) using Tecator equipment.

\section{Statistical analysis}

The data were analysed by one-way analysis of variance ANOVA and correlation analysis using Statgraphics 6.0 Plus software.

\section{RESULTS}

The percentage of SFA in rat serum (Table 3 ) did not change in response to the highly diverse supply of these acids in the diets (from $0.0187 \mathrm{~g} /$ day per animal in the control group to $0.6309 \mathrm{~g}$ /day per animal in the group receiving tallow). In the 1.d.m., however, a significantly smaller $\mathrm{P}<0.05$ content of these acids was found in rats fed a diet containing rape seed and linseed oils. These fats contain a smaller amount of SFA than the other sources of fat used in this study.

The fats used in this experiment led to differences in the percentage content of MUFA in rat serum (Table 3). A significantly lower $\mathrm{P}<0.01$ percentage of MUFA in the serum of rats receiving linseed and fish oils in their diets was found than, in particular, those fed tallow, lard or rape seed oil. The MUFA content in the 1.d.m. was proportional to the amount of these fats in the diets. The lowest percentage of MUFA was characteristic of the 1.d.m. of rats fed a diet with linseed oil.

The addition of linseed oib and fish oil led to a rise in the percentage content of PUFA in the serum of the experimental animals (Table 3), whereas in the muscle tissue, the highest level of PUFA was observed in the animals receiving linseed 
TABLE 3

Content of fatty acids in fat of diet, blood serum and longissimus dorsi muscle of rats, $\%$

\begin{tabular}{|c|c|c|c|c|c|c|c|c|}
\hline \multirow{3}{*}{$\begin{array}{l}\text { Fatty } \\
\text { acids }\end{array}$} & \multirow{3}{*}{ Samples } & \multicolumn{6}{|c|}{ Feeding groups } & \multirow[t]{3}{*}{ ANOVA } \\
\hline & & I & II & III & IV & V & VI & \\
\hline & & 0 & Tal. & Lard & R.O. & L.O. & F.O. & \\
\hline \multirow[t]{3}{*}{ SFA } & Feed & & 61.5 & 38.1 & 7.4 & 11.9 & 24.7 & \\
\hline & Serum & 40.5 & 37.1 & 38.3 & 37.0 & 38.0 & 40.2 & NS \\
\hline & Muscle & $35.1^{\mathrm{ab}}$ & $37.0^{b}$ & $37.3^{b}$ & $33.6^{\mathrm{a}}$ & $32.3^{a}$ & $36.4^{\mathrm{ab}}$ & $\mathrm{P}=0.0127$ \\
\hline \multirow[t]{3}{*}{ MUFA } & Feed & & 35.2 & 52.3 & 61.1 & 22.9 & 37.1 & \\
\hline & Serum & $26.3^{\mathrm{ab}}$ & $33.3^{\mathrm{b}}$ & $35.4^{\mathrm{b}}$ & $32.4^{\mathrm{b}}$ & $21.7^{\mathrm{a}}$ & $21.2^{\mathrm{a}}$ & $\mathrm{P}=0.0000$ \\
\hline & Muscle & $39.7^{\mathrm{ab}}$ & $40.3^{\mathrm{ab}}$ & $44.5^{b}$ & $45.0^{\mathrm{b}}$ & $37.4^{a}$ & $39.2^{\mathrm{ab}}$ & $P=0.0127$ \\
\hline \multirow[t]{3}{*}{ PUFA } & Feed & & 2.4 & 9.1 & 31.2 & 65.2 & 37.1 & \\
\hline & Serum & $33.2^{\mathrm{d}}$ & $29.6^{\mathrm{a}}$ & $25.9^{\mathrm{ac}}$ & $30.6^{\mathrm{a}}$ & $40.3^{\mathrm{bc}}$ & $38.5^{\mathrm{bc}}$ & $\mathrm{P}=0.0044$ \\
\hline & Muscle & $25.2^{\mathrm{ab}}$ & $22.7^{\mathrm{a}}$ & $18.2^{\mathrm{a}}$ & $21.2^{\mathrm{a}}$ & $29.2^{b}$ & $24.4^{\mathrm{ab}}$ & $\mathrm{P}=0.0015$ \\
\hline \multirow[t]{3}{*}{$\mathrm{P} / \mathrm{S}$} & Feed & & 0.1 & 0.2 & 4.2 & 5.5 & 1.5 & \\
\hline & Serum & 0.9 & 0.8 & 0.7 & 0.8 & 1.09 & 1.01 & NS \\
\hline & Muscle & $0.7^{\mathrm{ab}}$ & $0.6^{\mathrm{a}}$ & $0.5^{\mathrm{a}}$ & $0.6^{\mathrm{a}}$ & $0.9^{\mathrm{b}}$ & $0.7^{\mathrm{ab}}$ & $\mathrm{P}=0.0002$ \\
\hline
\end{tabular}

$\mathrm{a}, \mathrm{b}, \mathrm{c}, \mathrm{d}-\mathrm{P}<0.05$

oil, while the addition of tallow, lard as well as rape seed oil significantly $(\mathrm{P}<0.01)$ decreased the PUFA content of the 1.d.m. The large difference between the PUFA content of rape seed oil and tallow did not lead to any differences in the PUFA content in the tissues of rats in both of these groups.

The highest percentage content of n-6 fatty acids (Table 4) was found in the serum and muscles of rats in the control group, but it should be stated that the fats used in this study were not a rich source of PUFA ${ }_{n-6}$. The fish oil used in this experiment and, to a lesser degree, the linseed oil, lowered the percentage content of PUFA ${ }_{n-6}$ in the 1.d.m. and serum.

A markedly increased percentage content of PUFA ${ }_{n-3}$ in the serum and 1.d.m. of rats receiving linseed and fish oils in the experiment was noted. Similar tendecies were observed for the PUFA $_{n-3} / \mathrm{PUFA}_{\mathrm{n}-6}$ ratio. It may be worth noting that linseed oil had higher than fish oil PUFA ${ }_{n-3}$ content, while the PUFA $_{n-3}$ content in the serum of rats receiving fish oil was significantly higher in comparison with the content of these acids in the serum of rats fed linseed oil. In muscle tissue, however, the opposite tendency was noted.

\section{DISCUSSION}

In the reported experiment a stable percentage content of SFA in the serum and differentiated SFA content in the 1.d.m. in response to different sources of fat in the diets of rats were observed. 
TABLE 4

Content of fatty acids in fat of diet, blood serum and longissimus dorsi muscle of rats, $\%$

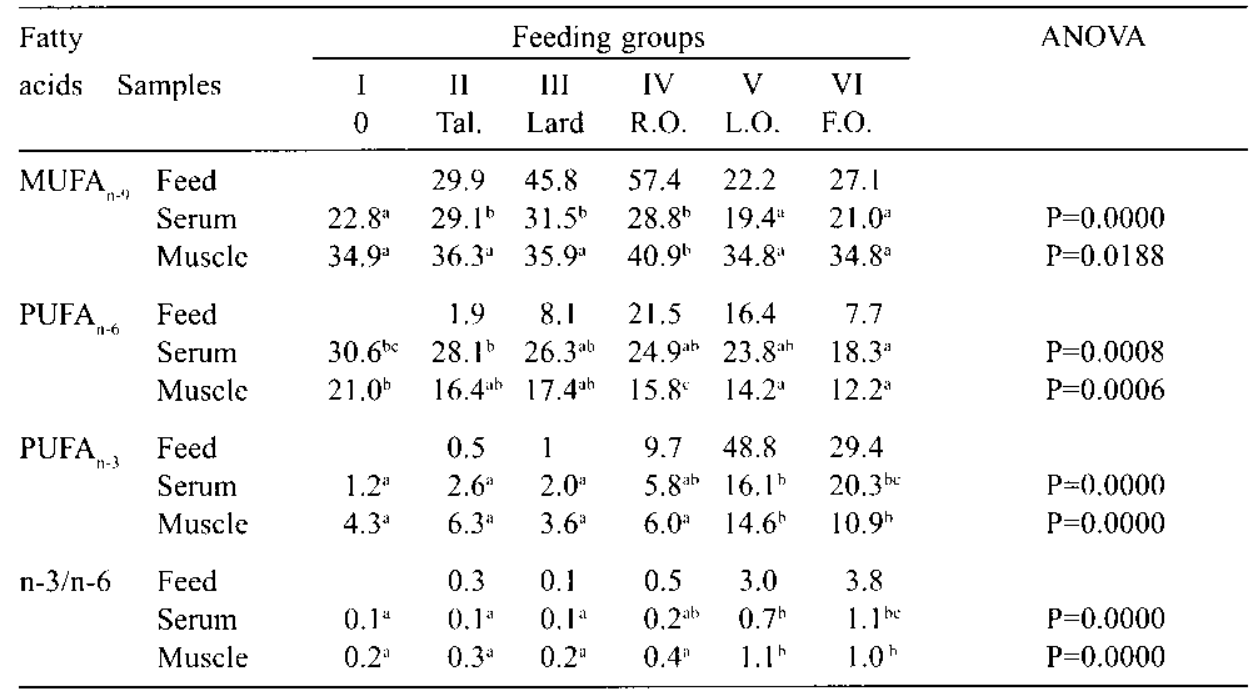

$\mathrm{a}, \mathrm{b}, \mathrm{c}, \mathrm{d}-\mathrm{P}<0.05$

The effects of quantitative and qualitative modifications of the fatty acid contents in tissues are undoubtedly related to the content of these acids in the diet. On the other hand, the incorporation of fatty acids into the body's lipids may be limited by the structure of the tissue being modified or the composition of the body fluids. It seems that the percentage share of phospholipids, cholesterol esters, free fatty acids, particularly triacylglyccrols, in the given lipid structure may be decisive about its susceptibility to modification. Phospholipids show a considerable tendency towards binding saturated fatty acids at the sn- 1 glycerol carbon, and unsaturated fatty acids (MUFA and PUFA) at the sn-2 carbon (Brockerhoff, 1967; Edwards-Webb and Gur, 1988; Clamp et al., 1997). It may be expected that those serum lipids that contain more than $35 \%$ phospholipids (Ziemlański and Topolows$\mathrm{ka}, 1991$ ) may show considerable resistance to attempts to decrease the percentage content of SFA. In the studies of some authors on various species, the SFA content of phospholipids was not found to decrease under the influence of diets enriched with PUFA (Ahn et al., 1996; Gachet, 1996; Vidrgen et al., 1997). According to others (Arbuckle et al., 1991; Calviello et al., 1997), the addition of fish oil lowered the percentage of SFA in phospholipids and cell membranes. In studies on pigs, Warnants et al. (1996) observed that the fatty acid content of feeds had a greater effect on changing the content of fatty acids in nonpolar lipids than in polar species.

In addition to lipids that are part of membrane structures and contain predominantly phospholipids, muscle tissue mainly accumulates triacylglycerols as the 
energy source for the body. Triacylglycerols that are deposited in intramuscular fat in the form of droplets in myocytes as well as adipocytes (Brouns and van der Vusse, 1998) are able to rather freely (in a less restricted manner than phospholipids) accumulate fatty acids. To a certain extent, this may explain the greater effect of dietary fatty acids on the percentage of these acids in muscles, as has already been observed by other authors (Cara et al., 1997; Lauridsen et al., 1997; Onibi et al., 1998). Triacylglycerols, however, also have certain tendencies to bind fatty acids from the SFA, MUFA, and PUFA groups at successive carbon atoms of the glycerol moiety, a trait that will hinder the process of modifying tissues in the direction of a considerable decrease in their SFA content.

In the present experiment, the observed tendency towards enriching serum and 1.d.m. lipids in PUFA in response to the inclusion of linseed oil and, to a lesser extent, fish oil, was most likely a result of replacing MUFA by PUFA. Similarly as in this paper (Table 5), Fremont (1995) also observed a negative correlation between PUFA and MUFA. The synthesis of endogenous monounsaturated fatty acids classified as MUFA increases under a deficit of PUFA. The activity of $\Delta-9$ desaturase, an enzyme that controls the synthesis of MUFA, may be regulated through the level of PUFA. Therefore, the inclusion of linseed oil in the diet, as well as fish oil, may have limited the synthesis of MUFA and created favourable conditions for the enrichment of tissues in PUFA. In studies on pigs, Morgan (1991) and Irie and Sakimoto (1992) observed similar tendencies in response to feeding fish oil.

In comparing the MUFA and MUFA $_{n-9}$ contents in serum, it can be seen that including linseed oil and fish oil in the diets of rats decreased the MUFA content of the acids that were not in the n-9 series. The authors' unpublished results indicate that this process most likely entails a reduction in the synthesis of $\mathrm{C} 18: 1_{n-7}$, and to a lesser extent, also of $\mathrm{C} 18: 1_{n-9}$.

The similar percentage content of PUFA in the serum and 1.d.m. of rats receiving tallow and rape seed oil may point to the fact that decreasing the degree of enriching tissues in MUFA as the result of the presence of PUFA is accomplished rather through inhibition of $\Delta-9$ desaturase, not through the preferential accumulation of PUFA over MUFA resulting from dietary supply.

Polyunsaturated fatty acids may belong to two series: PUFA ${ }_{n-6}$ and PUFA ${ }_{n-3}$. These acids may compete for sites in specific lipid compounds of particular tissues or body fluids, with different acids showing greater affinity to particular structures. In this experiment, linseed oil and fish oil had a significant effect on enriching lipids with PUFA $_{n-3}$; these observations corroborate the results obtained in various species (Ruiter et al., 1978; Froyland, 1992; Calviello et al., 1997; Lechowski et al., 1998). However, the incorporation of PUFA ${ }_{n-3}$ into blood lipids was significantly higher when fish oil was used in comparison with linseed oil. Several reasons for this can be envisaged. Limiting the enrichment of serum lipids in PUFA ${ }_{n-3}$ may be 
TABLE 5

Correlations between content $(\%)$ of groups and series fatty acids in serum and in longissimus dorsi muscle in rats $(n=48)$

\begin{tabular}{ccccc}
\hline \multicolumn{2}{c}{ In serum } & & \multicolumn{2}{c}{ In muscle } \\
\cline { 1 - 1 } \cline { 5 - 5 } fatty acids & cocfficient of correlation & & fatty acids & coefficient of corrclation \\
\hline SFA:MUFA & NS & & SFA:MUFA & $-0.283^{*}$ \\
SFA:PUFA & $-0.526^{* *}$ & & SFA:PUFA & NS \\
MUFA:PUFA & $-0.846^{* *}$ & & MUFA:PUFA & $-0.914^{* *}$ \\
n-9:n-6 & $-0.398^{* *}$ & & $n-9: n-6$ & $-0.721^{* *}$ \\
$n-9: n-3$ & $-0.422^{* *}$ & & $n-9: n-3$ & $-0.295^{* *}$ \\
$n-3: n-6$ & $-0.399^{* *}$ & & $n-3: n-6$ & NS \\
\hline
\end{tabular}

related to the greater supply of PUFA $_{n-6}$ in linseed oil than in fish oil. The negative correlation between PUFA ${ }_{n-6}$ and PUFA ${ }_{n-3}$ in serum (Table 5), also observed by other authors (Foote at al., 1990; Hrboticky et al., 1991), would point to the dominant position of the feed-derived PUFA ${ }_{n-6}$ over PUFA $_{n-3}$ in the process of creating some lipid structures in serum. Another important reason for this effect may be content of long-chain PUFA in fish oil. Eicosapentaenoic (EPA) and docosahexaenoic (DHA) acids show specific affinity towards specific lipid structures. EPA easily forms esters with cholesterol, while DHA is incorporated into the phospholipids of membranes (Bauer et al., 1997) which, albeit to a small degree, can lead to a rise in serum levels of PUFA $_{n-3}$ (EPA). Moreover, long-chain PUFA $_{n-3}$ may limit the synthesis of arachidonic acid, which potentially could increase the pool of PUFA (Philbrick et al., 1987; Swanson et al., 1988) by inhibiting the activity of $\Delta-6$ desaturase (Raz et al., 1998) and probably $\Delta-5$ desaturase (Horrobin, 1993). PUFA $_{n-3}$ inhibit the desaturation of PUFA ${ }_{n-6}$ more effectivelly than the converse relationship (Luostarinen, 1995).

In this experiment it was found that only in the case of rats receiving linseed oil was the PUFA ${ }_{n-3} /$ PUFA $_{n-6}$ ratio higher in the 1.d.m. than in serum. At the same time, no significant correlation was observed between tissue levels of PUFA ${ }_{\mathrm{n}-3}$ and PUFA $_{n-6}$. Also, a tendency was observed in the direction of lower PUFA, PUFA PUFA $_{n-6}$ contents in the l.d.m. of rats receiving fish oil in comparison with linseed oil. There exist the chance, then, that by inhibition the activity of desaturases, long chain PUFA $_{n-3}$ limit the synthesis of arachidonic acid (PUFA ${ }_{n-6}$ ), as well as the over-eighteen carbon fatty acids from the $\mathrm{n}-3$ series to which they belong.

\section{CONCLUSIONS}

It may be stated that the addition of $6 \%$ of various fats to the diets of rats did not affect percentage content of SFA in the lipid fraction of serum. The addition of 
linseed oil and fish oil favoured the enrichment of serum lipids in PUFA, as well as limited the synthesis of monounsaturated fatty acids belonging probably to the $n-7$ series. The addition of fish oil to the diet very effectively enriched serum lipids in PUFA $_{n-3^{3}}$. However, tendencies were found that pointed to the fact that dietary linseed oil facilitates the incorporation of PUFA ${ }_{n-3}$ into the lipids of the l.d.m. to a greater degree than does fish oil, particulary, that a negative correlation was not found between the percentage content of PUFA ${ }_{n-3}$ and PUFA in 6 in muscle tissue.

\section{REFERENCES}

Ahn D.U., Lutz S., Sim J.S., 1996. Effect of dietary alpha-linolenic acid on the fatty acid composition, storage stability and sensory characteristic of pork loin. Meat Sci. 43, 291-299

AOAC, 1990. Official Methods of Analysis of the Association of Official Analytical Chemists. 15 Edition. Chapter 32. Washington. DC

Arbuckle L.D., Rioux F.M., MacKinnon M.J., Hrboticky N., Innis S.M.,1991. Response of (n-3) and (n-6) fatty acids in piglets brain, liver and plasma to increasing, but low, fish oil supplementation of formula. J. Nutr. 121, 1536-1547

Bauer J.E., Mc Alister K.G., Rawlings J.M., Markwell P., 1997. Molecular species of cholesteryl esters formed via plasma lecithin; cholesterol acyltransferase in fish oil supplemented dogs. Nutr. Res. 17, 861-872

Brockerhoff H., 1967. A stereospecific analysis of triglycerides: an alternative method. J. Lipid Res. 8, 167-169

Broughton K.S., Welan J., Hardardottir I., Kinsella J.E., 1991. Effect of increasing the dietary (n-3) to $(n-6)$ polyunsaturated fatty acid ratio on murine liver and peritoneal cell fatty acids and eicosanoid formation. J. Nutr. 121, 155-164

Brouns F., van der Vusse G.J., 1998. Utilization of lipids during exercise in human subjects: metabolic and dietary constraints. Brit. J. Nutr. 79, 117-128

Calviello G., Palozza P., Franceschelli P., Bartoli G.M., 1997. Low dose eicosapentaenoic or docosahexacnoic acid administration modifies fatty acid composition and does not affect susceptibility to oxidative stress in rat erythrocytes and tissues. Lipids 32, 1075-1083

Cara R., Ruiz J., Lopez-Bote C., Martin L., GarciaC., Ventanas J., Antequera T., 1997. Influence of finishing diet on fattening acid profiles of intramuscular lipids, triglycerides and phospholipides in muscles of the Iberian pigs. Meat Sci. 45, 263-270

Clamp A.G., Ladha S., Clark D.C., Grimble R.F., Lund E.K., 1997. The influence of dietary lipids on the composition and membrane fluidity of rat hepatocyte plasma membrane. Lipids 32 , 179-184

Dolecek T.A., 1992. Epidemiological evidence of relationships between dietary polyunsaturated fatty acids and mortality in the Multiple Risk Factor Intervention Trial. Proc. Exp. Biol. Med. $200,177-182$

Edwarrds-Webb J.D., Gurr M.J., 1988. The influence of dietary fats on the chemical composition and physical properties of biological membranes. Nutr. Res. 8, 1297-1305

Folsh J., Lees M., Sloane-Stanley G.H., 1957. A simple method for the isolation and purification of total lipids from animal tissuc. J. Biol. Chem. 226, 497-509 
Foote K.D., Hrboticky N., MacKinnon M.J., 1990. Effect of suplementation of "infant formula" with n-3 fatty acids on brain synaptosonal, liver, plasma, and red cell lipids in the exclusively formula fed newborn piglets. Amer. J. Clin. Nutr. 51, 1001-1006

Fremont L., Gozzelino M.T., Hojjat T., 1995. Effects of moderate fat intake with different n-3 fatty acid sources and n-6/n-3 ratios on serum and structural lipids in rats. Reprod. Nutr. Dev. 35, 503-515

Froyland L., Vaagenes H., Asiedu D.K., Garras A., 1996. Chronic administration of eicosapentaenoic acid and docosahexaenoic acid as ethyl esters reduces plasma cholesterol and changed the fatty acid composition in rat blood and organs. Lipids $31,169-178$

Gachet C., 1996. Diets rich in saturated, n-3 and n-9 fatty acids differentially affect the fatty acid composition of phospholipids and function of rat platelets. Platelets 7, 269-276

Horrobin D.F., 1993. Fatty acid metabolism in health and disease: the role of D-6-desaturase. Amer. J. Clin. Nutr. 57, 732-737

Hrboticky N., MacKinnon M.J., Innis S.M., 1990. Effect of linoleic-acid-rich, vegetable oil formula for infants on tissue fatty acid accretion in the brain, liver, plasma and erythrocyte of newborn piglets. Amer. J. Clin. Nutr. 51, 173-182

Irie M., Sakimoto M., 1992. Fat characteristics of pigs fed fish oil containing eicosapentaenoic and docosahexaenoic acids. J. Anim. Sci. 70, 470-478

Keys A., Menotti A., Karvonen M.J., 1986. The diet and 15 year death rate in the seven countries study. Amer. J. Epidemiol. 124, 903-915

Lauridsen C., Buckley D.J., Morrissey P.A., 1997. Influence of dietary fat and vitamin E supplementation on $\alpha$-tocopherol levels and fatty acid profiles in chicken muscle membranal fraction and on susceptibility to lipid peroxidation. Meat Sci. 46, 9-22

Lechowski R., Sawosz E., Kluciński W., 1998. The effect of oil preparation with increased content of $\mathrm{n}-3$ fatty acids on serum lipid profile and clinical condition of cats with miliary dermatitis. $J$. Vet. Med. 45, 417-424

Mattson F.H., Grundy S.M., 1985. Composition of effects of dietary saturated, monounsaturated and polyunsaturated fatty acids on plasma lipids and lipoproteins in man. J. Lipid Res. 26, 194-202

Morgan C.A., 1991. Manipulation of the fatty acid composition of pig meat lipids by dietary means. J. Sci. Food Agric. 58, 357-368

National Research Council, 1978. Nutrient Requirement of Laboratory Animals. National Academy of Sciences, Washington, DC

Onibi G.E., Scaife J.R., Murray I., Fowler V.R., 1998. Use of $\alpha$-tocopherol acetate to improve fresh pig meat quality of full-fat rapeseed fed pigs. J. Amer. Oil Chem. Soc. 75, 189-198

Philbrick D.J., Mahadevappa V.G., Ackman R.G., Holub B.J., 1987. Ingestion of fish oil or a derived n-3 fatty acid concentrate containing eicozapentaenoic acid (EPA) affects fatty acid composition of individual phospholipids of rats brain, sciatic nerve and retina. J. Nutr. 117, $1663-1670$

Raz A., Kamin-Belsky N., Przedecki F., Obukowicz M., 1998. Dietary fish oil inhibits $\Delta-6$ desaturase activity in vivo. J. Amer. Oil Chem. Soc. 75, 241-245

Ruiter A., Jongblood A.W., van Gent C.M., Danse L.H.J., Metz S.H., 1978. The influence of dietary mackercl oil on the condition of organs and blood lipid metabolism in the young growing pigs. Amer. J. Clin. Nutr. 31, 2159-2166

Swanson J.E., Black J.M., Kinsella J.E., 1988. Dietary menhaden oil: effects on the rate and magnitude of modification of phospholipid fatty acid composition of mouse heart and brain. Brit. J. Nutr. 59,535-545

Vidrgen H.M., Agren J.J., Schwab U., Rissanen T., Haninen O., Uusitupa M.I.J., 1997. Incorporation of n-3 fatty acids into plasma lipid fractions and erythrocyte membranes and platelets 
during dietary supplementation with fish, fish oil and docosahcxacnoic acid-rich oil among healty young men. Lipids 32, 697-705

Warnants N., Van Oeckel M., Boucque Ch.V., 1996. Incorporation of dietary polyunsaturated fatty acids in pork tissues and its implications for the quality of the end products. Meat Sci. 44 , $125-144$

Zicmlański Ś., Topolowska J., 1991. Food Fats and Organism Lipids (in Polish). PWN, Warszawa

\section{STRESZCZENIE}

Wplyw różnych thuszczów w diecie na zawartość kwasów tłuszczowych w surowicy krwi i mięśniu najdłuższym grzbietu szczurów

Cztcrdzicści osicm szczurów (Wistar), podzielonych na 6 grup, żywiono półsyntetyczną mieszanką z udziałem $(6 \%)$ różnych rodzajów tłuszczu; I - grupa kontrolna, II - łój wołowy, III smalec, IV - olej rzepakowy, V - olcj lniany, VI - olej rybny. W doświadczenju określono procentową zawartość kwasów thuszczowych w surowicy i mięśniu longissimus dorsi metodą chromatografii gazowej.

Tłuszcz diety nie wpłynął na zawartość procentową nasyconych kwasów tłuszczowych (SFA) w surowicy krwi szczurów. W surowicy i tkance mięśniowej zwiększyla się procentowa zawartość wiclonienasyconych kwasów tluszczowych (PUFA), zmniejszyła zawartość jednonienasyconych kwasów tłuszczowych (MUFA). Olej lniany oraz rybny wpłynął na zwiększenie zawartości PUFA $_{n-3}$ w surowicy i mięśniu. W tkance mięśniowej w przeciwieństwie do surowicy nie stwierdzono ujemnej korelacji pomiçdzy PUFA in-3 PUFA $_{n-6}$. 